\title{
Construction Policy Renewal of Criminal Law Through the Formulation of Corruption in the Penal Code Draft
}

\author{
Subaidah Ratna Juita* \\ Faculty of Law \\ Semarang University \\ ratna.juita@usm.ac.id
}

\author{
Deni Setya Bagus Yuherawan \\ Faculty of Law \\ Trunojoyo University Of Madura \\ deniyuherawan@trunojoyo.ac.id
}

\begin{abstract}
The renewal of criminal law covers the main issues relating to the three fundamental issues in criminal law, i.e. prohibited acts, persons/corporations as subjects that conduct prohibited acts, and criminal. In the draft of the Penal Code (RKUHP), as one of the renewal efforts in the formulation of a criminal act of corruption outlined in chapter XXXII starting from article 688 to article 702 . With the formulation of the criminal act of corruption that is formulated in the RKUHP, will directly override the Corruption law Eradication Act even though this law is special because the substance of the RKHUP articles is oriented to make the Corruption criminal Act a common criminal act and not through the extraordinary handling. As part of the mechanism of criminal law enforcement at the formulation stage, and as a policy process deliberately planned, then through the discussion of writings conducted using the method of normative juridical approach it intends to describe, study, and explain analytically about the construction of the policy of renewal of criminal law through the formulation of criminal corruption in the criminal draft.

Keywords: construction policy, the criminal act of corruption, penal code draft
\end{abstract}

\section{INTRODUCTION}

The Criminal Code is the parent of the criminal law in Indonesia, in his language called Wetboek van Strafrecht. This means that the PENAL code is Dutch colonialism that until now still used. The implementation of the CRIMINAL code in Indonesia began with Koninklijk Besluit (the King's decree) to enact Wetboek van Strafrecht voor Nederlandsch Indie in Indonesia as a derivative of the Dutch WvS in January 1918. [1]

After Indonesia declared its independence in the year 1945, to fill the void of criminal law, the Indonesian government continued to enforce WvSvNI based on Article II transitional rules UUD 1945 which was then born Law No. 1 the year 1946 on criminal law regulation. The enforcement of the Book of Criminal Law in all the territories of the Republic of Indonesia or the new nation was conducted on 20 September 1958, with the enactment of law No. 73 year 1958 on declaring the validity of law No. 1 of 1946 of the Republic of Indonesia on criminal law regulation for all regions of the Republic of Indonesia and changing the Code of Criminal law. As stated in article 1 that reads, "Law No. 1 of 1946 of the Republic of Indonesia on criminal law rules shall apply to all territories of the Republic of Indonesia."[2]
The criminal CODE for the inheritance of Dutch colonialism can no longer follow the dynamism of people's lives. Its overly rigid nature has eliminated the sense of justice which is the purpose of the creation of the law itself. This is because the chapters in the criminal CODE are deemed to be no longer appropriate with the development of increasingly complex crimes and violations. To cope with this, the rules are more specific and systematic in terms of the development of crime and offense, especially those with extraordinary nature. The reason that these more specific and systematic rules can help and protect the PENAL code from the development of more complex criminal acts. However, provisions of the special rules regarding the formulation of criminal norms, criminal sanctions, and criminal events contain a method of law that deviates from the general provisions of criminal law, both material criminal and formyl criminal, so that there is a concentration of criminal norms and criminal sanctions. The implication raises the system of formulating criminal norms and the formulation system of criminal sanctions threat into the Dual System.[3]

With the reason for the Dual System, the renewal of criminal law is necessary and must be done thoroughly with the intention that there is no disparity in the efforts of countermeasures or the enforcement of criminal law so that criminal material is carried out with extra caution, namely by observing the context of the society in which the criminal law is enforced and still uphold the values of civilized humanity.

The draft of the Criminal Code (RKUHP) is an important step in the renewal of Indonesian criminal law. This update needs to be done for various reasons, namely philosophical, political, sociological, and practical reasons. The philosophical legislation that originated in the colonial government, including the PENAL code, has to be replaced because it is made with a different foundation of philosophy. Many sociological chapters in the PENAL code also do not conform to the prevailing values as well as the needs of society in life as an independent nation. While the advancement of science and technology, which poses a side impact in the form of a new criminal offense, has made various criminal settings in the outdated criminal CODE.

Partially renewal of criminal law has been done by the Government when making some changes to the PENAL code. The change is made through legislation that 
directly changes the chapters in the criminal CODE or through legislation governing special criminal acts. Other changes to the CRIMINAL code occur through various COURT decisions, stating that a clause does not apply or applies conditionally (conditional).[4]

In the RKUHP, as a renewal effort is the formulation of the criminal act of corruption outlined in chapter XXXII starting from chapters 688 to Section 702. The discussion of the chapters, many of which brought about the problem, especially in the countermeasures and its enforcement that is considered corruption crime which is special nature and is an Extra-Ordinary Crime being a common criminal act and/or a regular crime. If the corruption is entered in the RKUHP then the Corruption criminal act will lose the specificity which affects the pattern of handling the case. Meaning it will eliminate the nature of corruption acts as "extraordinary crimes", becoming a regular crime. Corruption criminal treatment including the authority of the examination, in the investigation process, investigation and prosecution is no longer the realm of KPK. Even a special criminal offense attorney. The handling of corruption will be fully police authority.

Based on the background above, intending to complete the literature, the discussion outlined in this article is getting the urgency, and to facilitate the discussion then the problem in this article is related to, how the construction policy for criminal law renewal through the formulation of corruption in the PENAL code?

\section{RESEARCH METHOD}

To answer the problem in this article, a normative juridical research method.

\section{RESULT AND DISCUSSION}

\section{Construction of the Delik corruption formulation policy in current legislation}

Corruption itself is an activity of using power to profiled or retrieve money that is not hers. As it was once said by Lord Acton "Power Tend to Corrupt, and absolute power Corrupt absolutely" (power tends to be corrupt, and the absolute power tends to absolute corruption). Based on that view, it can be seen that power plays a crucial role in the act of corruption. Speaking of power it will look a position. The position is a symbol of power that can overwhelm something in half or absolutely. This department is identified with the structural office of Permertahan and high officials in an agency/institution and private parties.

To eradicate corruption among the organizers of the state formed a regulation of the MPR Decree no XI/MPR/1998 on the operator of the clean and Free state of corruption and nepotism. According to this decree in the implementation of the state, there have been business practices more profitable a certain group of fertilizing corruption, collusion, and nepotism is also known as $\mathrm{KKN}$, involving state officials with entrepreneurs to damage the joints of State organizing in various aspects of national life.[4]

Then in the year 1999 the publication of Law No. 28 of 1999 on the state organizer clean and free of corruption, collusion, and nepotism. KKN problem has been damaging the national order of life. Therefore, it is the determination of all nations in the world to eliminate and reduce the level of intensity, quality, and quantity in the effort to create clean governance and good governance, corruption is difficult to eradicate.

The policy of the criminal law formulation in the attempt to tackle the current corruption Act has indeed undergone various changes, in which the changes were made given the rapid development of corruption. Even according to some members or experts of criminal law and criminology as outlined in Chapter I and chapter II corruption is described as a disease in its development not only damaging or detrimental to the financial and economic state but has exceeded the boundaries that are damaging or detrimental to the economy of the people.

The development of corruption, especially in the sphere of malpractice and bribery, has mastered every joint life, which in the end every society is faced with difficulties while dealing with state officials who are supposed to be able to serve every need of society without having to pay for the officers. Thus it is necessary that the arrangement comprehensively governs corruption crimes. Published law number 31 the year 1999 on the eradication of corruption crimes as an advanced arrangement of the Law number 28 the year 1999. Apparently, in a relatively short time, this law is effective poses different interpretation problems from scholars. Besides the switching conditions that are not explicitly listed, the reversed proof issue is again discussed. The concept of the load reversal proving is not expressly formulated, so it is believed to eliminate the severity of corruption as well as experiences that have been implemented in other countries.[5]

The amendment was then made to the law by the issuance of Law No. 20 of 2001 concerning the amendment to Law No. 31 of 1999 on corruption eradication. This law is a refinement to create a reversed proof aimed at the defendant to prove that he was innocent.

In-Law No. 31 of 1999 as amended by law number 20 of 2001, according to Seno Adji there are several scopes of corruption, namely: (a) the group of proceedings relating to the financial loss of the country. (b) Groups of dealers relating to bribes bribery and gratification. (c) The Delic group associated with the evasion in office. (d) a criminal act group associated with extortion in office. (e) Groups of deals related to the contractor, the supplier, and the counterparty.[6]

Nevertheless, the prawns, there is still a juridical issue in formulating corruption crimes, which can lead to the difficulty of operationalization of the CRIMINAL code as a master system in bridging the eradication of corruption crimes. The issue: (a) has not formulated juridical restrictions or juridical notions of corruption crimes in the event of a malicious agreement, while the evil agreement contained in article 88 of the criminal CODE is a term stipulated in chapter IX which is unlikely to be operationalized considering article 103 the criminal CODE requires that the provisions of chapter I until chapter VIII apply to deeds that by other provisions of the legislation are threatened with the criminal. Similarly, the term "paid" which is a juridical term, has not been governed by this law. (b) Not to list the qualification of whether as a "breach" or 
"crime" that the criminal CODE cannot be operationalized against corruption crimes.

\section{Construction of the Criminal law update policy through the draft of corruption in the Penal Code}

The development of corruption in Indonesia is still relatively high, while Pemberantasannya is still very slow. In this regard, Romli Atmasasmita stated that corruption in Indonesia is already a flu virus that spreads throughout the body of government since the 1960s Pemberantasannya measures are still intermittently until now.[7] It is further said that corruption relates also to power because the ruler can misuse his power for personal, family, and the chronology.[7]

Corruption crimes are a violation of social rights and economic rights of society so that the crime of corruption can no longer be classified as ordinary crimes but has become an extraordinary crime (extraordinary crimes). So in the Pemberantasannya effort can no longer be done using ordinary efforts, but demanded in extraordinary ways (extraordinary enforcement).[4] In his book, Romli Atmasasmita argues that in dealing with the eradication of corruption that has been an extraordinary crime need to be established a corruption eradication agency:

Corruption in Indonesia is already a crime that is a tremendous crime (extraordinary crimes) so that the demands of the availability of a very extraordinary and sophisticated legal device and institutions that deal with corruption can not be avoided anymore. May the Indonesian people agree that corruption should be prevented and exterminated from the homeland because corruption has proved to be very decapitated the people have even achieved a violation of the economic and social rights of the Indonesian people. The issue of eradication of corruption in Indonesia is not only legal and law enforcement issues but rather severe social and social psychology issues with legal issues, so it is obligatory to be simultaneously addressed. Corruption is also a social problem because corruption results in an equalisation of welfare and is a matter of social psychology because corruption is a social disease that is difficult to heal ".[4]

The renewal of criminal law is a policy that demands the renewal of all aspects that touch a philosophical facet, i.e. a change or orientation to the principles to the level of the underlying values. Indonesia is now working to update criminal law by codifying the criminal CODE. There are 3 reasons, according to Sudarto, which is the urgency to renew the criminal CODE, namely:

First, the political reason, as an independent country, is reasonable that the Republic of Indonesia when having its CRIMINAL code that is national for national pride. Secondly, for sociological reasons, the criminal CODE must reflect the cultural values of a nation. WVS has not been suited to community needs. Third, practical reason is based on that the PENAL code is a translation from the Dutch language. But in reality, Indonesian law scholars who can understand the Dutch are the fewer principles.[8]

Based on the three reasons for the legal reform, Governments and experts are currently working on the PENAL code. One of the concepts of this RKUHP includes all criminal acts previously governed by special legislation and then compiled into a codification. By incorporating the concept of a special criminal offense into the criminal CODE that underlies the common crime criteria (generic crimes, independent crimes), among others:

a. is a malicious act that is independent (not referring to or depends on the violation of the provisions of the administrative law in the legislation in question);

b. The validity of relatively sustainable, meaning not associated with the problem of the procedure or administration process (Specific crime, administrative dependent crimes); Dan

c. The threat of punishment is more than 1 (one) year of criminal deprivation of independence (prison/confinement). [9]

Furthermore, according to Barda Nawawi Arief, the background and the holding of a criminal law renewal can be reviewed from a sociopolitical, socio-philosophical, sociocultural aspect, or various aspects of policy (custom social, criminal policy, and law enforcement policies).[10] As a reorientation effort, and to achieve the ideal national criminal law renewal policy, the criminal policy is faced with two problems, such as a) What action should be a criminal act, b) What actions should be used or imposed on the violator.[11]

Renewal of a criminal law system (Penal reform system) must make changes to the substance of criminal law, renewal of criminal legal structure, and renewal of criminal law culture. Then the renewal of criminal law should be done with the policy approach because it is only part of a policy step or "policy" (i.e. part of political/enforcement, criminal law politics, criminal politics, and social politics).[10]

One of the criminal acts included in the concept of RKUHP is criminal corruption. The urgency of the compilers of the RKUHP to incorporate corruption crimes into the RKUHP is that there is a criminal law system (both the criminal law and the Formyl criminal law and the criminal law) applies to all criminal acts.[12]

Barda Nawawi Arief stated that the renewal of criminal law through the PENAL code is conceptualized by codifying generalized criminal (generic crime) only, by allowing special administrative crimes to be outside the criminal CODE. The assertion of the still existence of special criminal law (a criminal offense that is specifically regulated outside codification) is also declared by Harkristuti Harkrisnowo. He said, among others: "With article 211 RKUHP, it is an open opportunity to regulate lex specialist outside the criminal CODE. This article broke the argument that in the future with this law, the criminal law outside the PENAL code is lost. Precisely after the RKUHP is enforced as lex generalist or general provisions, the 
existence of special criminal law that serves as Lex specialist is still recognized."[12]

However, such criteria must not be absolute, because the choice of criminal (specific) crimes which will be governed in codification or fixed in the LAW itself must be adjusted to the conditions and circumstances of the community in which the law will be enforced, particularly the moral and public view of the criminal act. Besides, it must be adjusted to the purpose to be achieved by setting the criminal, both into codification and beyond codification.

Consideration of these matters, related to various approaches in criminal law politics (strafrechts Politiek/penal policy). According to Soedarto, implementing criminal law politics means the effort to create a criminal legislation that is appropriate to the circumstances and situations at a time and for the future. This also means holding elections to achieve the best result of criminal legislation, in terms of qualifying justice and usability.[9] The policy-oriented approach in criminal law politics submitted above wishes for the arrangement of criminal acts and their students must be attributed to the achievement of certain objectives of criminal politics, social politics, or the policy of national development of a country.

In the RKUHP, as an update attempt is the formulation of the criminal act of corruption set out in chapter XXXII starting from chapters 688 to Section 702, where corruption crimes in the RKUHP are divided into two types of criminal acts namely, bribery and misuse of authority that is detrimental to state finances. Broadly, the RKUHP in the formulation of articles take the Fundamentals of a criminal act in the Corruption Act (LAW No. 31 of 1999 as amended by LAW No. 20 of 2001), namely as follows;

I. Article 688 RKUHP;

II. Article 689 RKUHP;

III. Article 690 RKUHP;

IV. Article 691 RKUHP;

V. Article 692 of the RKUHP;

VI. Article 693 RKUHP;

VII. Article 694 RKUHP;

VIII. Article 695 RKUHP;

IX. Article 696 RKUHP;

X. Article 697 RKUHP;

XI. Article 698 RKUHP;

XII. Article 699 RKUHP;

XIII. Article 700 RKUHP;

XIV. Article 701 RKUHP;

XV. Article 702 RKUHP.

Any person who commits a criminal offense as referred to in article 666, section 667, article 668, article 670, article 671, article 688, article 689, article 690, article 691, article 693, article 694, article 695, article 696, article 697, article 698, article 699, article 700, and article 701 as long as the deed is detrimental to the state's finances or economy, sentenced to criminal in accordance

The discussion of the chapters, many of which brought about the problem, especially in the countermeasures and its enforcement that is considered corruption crime which is special nature and is an extraordinary Crime being a common criminal act and/or a regular crime. Delik corruption incorporated into the RKUHP is no longer classified as extraordinary crimes as certain criminal acts are taken seriously, such as criminal acts of terrorism and money laundering crimes that are in the RKUHP expanding things can be added to the experiment until the deed of preparation. This does not apply to criminal acts of corruption, but the provisions of Article 27 (1) UNCAC mandate it.

Under the provisions of article 22 of the RKUHP, the criminal for the assistance, including the criminal act aid of corruption is threatened with the maximum criminal minus a third, when it is evident in the Criminal Eradication Act is determined that the criminal threat to the aid is equal to the criminal threat to the perpetrator. Regarding the formulation of the criminal act corruption in the RKUHP, which is included in the criminal act of corruption are a criminal act position, criminal act of corruption, and criminal act misdeeds. But if examined, the substance of the chapters contained in the RKUHP formulated only describes the elements of the Delic, without mentioning the Juridi's qualifications. The substance of the chapters also does not formulate the basic principles of errors in the form of intentional (dolus) and negligence (culpa) which should be used as a subjective element in an event, deed, or criminal act. This fundamental principle is necessary to determine whether someone who commits a criminal offense may be held a criminal liability to him (Toerekeningsvatbaarheid) or his actions can be categorized as inability responsible (on Toerekeningsvatbaarheid).

On the other, a strict and vicarious liability principle cannot be applied, especially to corporations committing corruption crimes because the substance of the chapters in the RKUHP expressly does not govern how the concept of accountability is set. Furthermore, the RKUHP no longer knows the criminal payment of substitutes as known in article 18 paragraph (1) item B of the ACT on corruption crimes, whereas the existence of such criminal type is an essential thing in the context of restoring the state's financial losses.

Because the absence of subjective elements of a proceeding contained in these chapters will have implications for its enforcement efforts (application) where the element of error in the form of intentional, negligence, and action against the law is difficult to prove so that it can not be held accountable. Therefore, as the provisions of article 10 of the RKUHP, a formula of corruption in the RKUHP which has become a general proceeding will weaken even be able to eliminate the strength and certainty of the law in Law No. 31 of 1999 as amended by Law No. 20 the year 2001 because in principle if there is a change in the legislation after the deed is done, then it can be applied the

\section{CONCLUSION}

Based on the explanation above, it can be concluded that by the formulation of the criminal acts of the corruption outlined in chapter XXXII commenced from article 688 to Section 702, Rkhup, then the construction of policy renewal of criminal law through the formulation of proceeding corruption in the draft Criminal code is the government's effort to adjust the development of criminal law to standardize the formulation of criminal law norms and the threat of criminal sanctions and to avoid the nature of the exceptionality or criminal law. This 
indicates that the inclusion of a criminal offense into the RKUHP is not based on the fulfillment of criteria for determining the criminal norm that must be entered in the RKUHP, but solely for the benefit of standardization drafting the norms and threats of sanctions, which can be done in other ways, such as the revision of the Corruption Eradication Act.

\section{ACKNOWLEDGMENT}

Construction of the policy of criminal law renewal through the formulation of the CODE of corruption in the criminal draft should always be based on strong philosophical, sociological, and juridical foundations. In this case, should always refer to the values of Pancasila. The paradigm of thinking should always lead to progressive and responsive law because a formal legalistic paradigm is no longer able to achieve a sense of community justice. In this case, it is hoped that there are breakthroughs in criminal law to realize the objectives of the law, namely justice, benefit, and legal certainty. The most important thing here is, if the government has made the renewal of criminal law through the formulation of corruption in the Penal Code, it must be immediately completed by setting aside the various political interests.

\section{REFERENCES}

[1] BPHN, "http://hukumpidana.bphn.go.id/sejarah-kuhp." .

[2] Republic of Indonesia, The principle of Lex Specialis Derogat Legi Generali in criminal law enforcement. Depok. 2014.
[3] Mudzakkir, "Model dan Kebijakan Kodifikasi Serta Perumusan Delik Korupsi dalam RKUHP," Focus Gr. Discuss. dengan tema "Pengaturan Delik Korupsi dan Implikasi Hukumnya terhadap Prakt. Pemberantasan Korupsi di Indones. yang diselengarakan oleh Komisi Pemberantasan Korupsi, 2013.

[4] E. Djaja, To design a corruption criminal court: The implications of the verdict of the Constitutional Court No. 012-016-019/PPU-IV-2006. Jakarta: Sinar Grafika, 2010.

[5] E. Danil, Corruption: concepts, criminal acts, and Pemberantasannya. Jakarta: Raja Grafindo, 2011.

[6] S. A. Indriyanto, Corruption of State apparatus policy and criminal law. Jakarta: Diadit Media, 2006.

[7] Atmasasmita Romli, Around corruption issues, national aspects, and international aspects. BANDUNG: Mandar Maju, 2004.

[8] Soedarto, Law and criminal law. BANDUNG: Alumni Publisher, 1981.

[9] B. N. Arief, New Criminal BILL: a restructuring/reconstruction of the Indonesian crime system., Mold-4. Semarang: The issuing agency of Diponegoro University, 2009.

[10] B. N. Arief, Criminal Law policy: development of new concept drafting. Jakarta: Prenada Media Group, 2010.

[11] I. S Heru Pratama, criminal politic. Yogyakarta: Atma Jaya University, 2007.

[12] S. Agustina, "corruption arrangement criminal in the framework of renewal of criminal law," Present. Rev. Act. Penal Code Corrupt. Erad. effort, Organ. by ICW, J5, 2015. 